European Journal of Pragmatism and American Philosophy

III-1 | 2011

Contemporary Reassessment of William James a

Century Later

Vincenzo costA, Fenomenologia dell'intersoggettività

Roma, Carocci, 2010

\title{
Giovanni Maddalena
}

\section{OpenEdition}

\section{Journals}

Electronic version

URL: http://journals.openedition.org/ejpap/881

DOI: 10.4000/ejpap.881

ISSN: 2036-4091

Publisher

Associazione Pragma

Electronic reference

Giovanni Maddalena, «Vincenzo costa, Fenomenologia dell'intersoggettività », European Journal of Pragmatism and American Philosophy [Online], III-1 | 2011, Online since 01 July 2011, connection on 24 September 2020. URL : http://journals.openedition.org/ejpap/881 ; DOI : https://doi.org/10.4000/ ejpap.881

This text was automatically generated on 24 September 2020 .

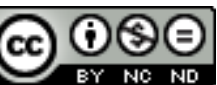

Author retains copyright and grants the European Journal of Pragmatism and American Philosophy right of first publication with the work simultaneously licensed under a Creative Commons AttributionNonCommercial-NoDerivatives 4.0 International License. 


\title{
Vincenzo costa, Fenomenologia dell'intersoggettività
}

Roma, Carocci, 2010

\author{
Giovanni Maddalena
}

\section{REFERENCES}

Vincenzo costa, Fenomenologia dell'intersoggettività, Roma, Carocci 2010

\section{Introduction}

1 Can phenomenology and pragmatism, two early twentieth century theories, be alive today and furnish a valid possibility in our philosophical landscape? Moreover, can they work together? The operation does not seem impossible since Peirce himself held a phenomenology, which is an indispensable part of his never-finished system; James's psychology is often a phenomenology, and Husserl recognized James as an interesting author because of his phenomenological insights. However, the parochial attitude has often undermined the possibility of a common path, notwithstanding noble attempts to use them together (i.e. Rosenthal \& Bourgeois 1983). But, there are a few obstacles.

2 The first crucial point is the interpretation of Husserl's thought. Reading Husserl's thought in an idealist way does not permit to use his phenomenology for a completely new conception of being as the one held by pragmatists.

3 Second, it is not clear where the intersection has to be fixed. Where could phenomenology and pragmatism find a unifying concept or moment? Even Peirce's classification of science that lists phenomenology and semiotics, indicating in the first the origin of the principles of the second one, does not solve the problem precisely, even though it suggests a possible strategy. 
4 Third, contrary to what happened at the beginning of the last century, phenomenology and pragmatism should become clear about the new paradigms they foster. In their original version they proclaimed the revolution but they never got there, or never got far enough.

5 For these reasons, Costa's book on intersubjectivity is a good starting point and very useful to overcome at least the first obstacle, and producing some insightful comments on the other two.

\section{Milan School of Phenomenology and Costa's Reading of Intersubjectivity}

6 There are at least as many ways to read Husserl as to read Peirce. Costa belongs to an Italian phenomenological school, based in Milan, and founded by Antonio Banfi and Enzo Paci at the half of the last century. Various phenomenological streams stemmed from their lessons. One of the most important is the one led by Giovanni Piana in the '60s. Piana and his followers read Husserl in a realistic way, pointing out the difference between genetic and static approach to phenomenology, the power of passive syntheses as anti-subjectivist moment in the formation of the world, and the methodic relevance of Husserl's reductions (Costa, Franzini \& Spinicci 2002).

7 Costa is a powerful representative of this school of thought. Besides that, he chooses a topic as intersubjectivity, which amplifies this approach, and he has the gift of clarity.

According to Costa, Husserl never thought of founding intersubjectivity on a solipsistic ground. The phenomenological analysis that reduces everything to the certainty of the lived self is "not a dogma but a structure" (56). Moreover, it is a static structure that has nothing to do with the dynamic genesis of the self, which is naturally social.

The static structure of the self accounts for the difference between the phenomenological perception of our "experience" (Erlebnis) and any others'. This difference explains why we know we are not lying while we never can say the same about others. From this difference we can understand that the order of time is essential to read consciousness in a phenomenological way: my original Erlebnis belongs to a specific current of consciousness, to an ordered series of experiences that I can observe directly, while I can enter another's consciousness only indirectly.

10 I think that phenomenology has to instruct or to simply to remind pragmatists of this crucial difference between our perception of ourselves and of the world. In Peirce's phenomenology there is a phenomenological difference between firstness, secondness and thirdness which should catch the same issue. And some sort of recognition of this phenomenic difference, or rather, the concern for it, is certainly present in James' psychology, and in Dewey's and Mead's logics. However, sometimes scholars have downplayed this phenomenological background focusing on more attractive semiotic and logic paths loosing the importance of this background.

11 Costa explores this fundamental theme in comparison with different approaches: Lacan's psychoanalysis, Scheler's, Schütz's, Sartre's phenomenology, cognitive sciences. His argument is that every other approach has to presuppose the phenomenological relationships that are founded in the experience of the self. Statically, then, the world and its sociality are founded by the self, and not the other way around: "if I had no experience of my action in my body, to be active in my body and to express myself in it, 
I could not apperceive a different body as expression of another living consciousness" (89).

12 Here one may discover the critical point. Passing from the original experience of the self to others' consciousness, Costa relies upon Husserl's well known concept of analogy. He tries to read it as realistically as possible maintaining that the late Husserl understood analogy as a "passive intentionality," an already-happened phenomenological synthesis that implies a necessary cross-reference among contents (90-1). Here analogy is not a form of reasoning but a form of intentionality. I will return to this point later.

Once ascertained the passage from the self to the other, Costa becomes a pragmatist. $\mathrm{He}$ denies almost any form of "empathy" in favor of an interactionist view of the world (110) so that signs, tools, culture have to be explained reading and interpreting another person and not magically entering his self-consciousness. Moreover, Costa uses Mead's concept of significant gesture to account for the birth of culture, namely for the interpretation of another one through external signs (162). Originally, Costa ties comprehension to the important dimension of totality without which signs could only partially work. Without reference to totality, they work only as they work in animals, as sense stimuli, but they cannot have the teleological reference to everybody and every time in the future, which are typical of human actions. "I'll do that for $\mathrm{x}$ and $\mathrm{y}$," implies somehow the whole history and that is why "promises" and similar acts are so important in human relationships: they express this reference to totality. It is a kind of remark that matches Peirce's insistence on the teleological drive present in signs (Hulswit 2002; Short 2007).

Costa's reading succeeds in giving us a thorough phenomenological account that encompasses many, and some of the best, insights of contemporary philosophy. He can combine his pattern with both pragmatism and hermeneutic narrative patterns rescuing from each scheme the part more akin to clarity and common sense.

\section{The Point of Intersection}

We saw the critical point is the intersection between phenomenology and semiotics. The crucial point is "analogy," the kind of phenomenological operation that presides over our initial attribution of a mind to others. Correctly, Costa focuses on defending analogy from biological innatism and categorical transcendentalism, but he maintains that analogy is not a reasoning as well because it is an "ante-predicative association" (that comes before any predication), "a unitary synthetic phenomenon" (91, 92). Here the Husserlian belonging is winning out against the usual respect for common sense that Costa shows in his book. Why is "association" not a possible part of a reasoning? Why is "synthesis" not a reasoning, even if Costa himself reads it as a set of "internal rules of reference"? Peirce's semiotic explains association as indexical, and internal cross references as iconic driven. They are the first part or move of reasoning, both statically and genetically conceived. The intersection between phenomenology and semiotics does not come with Mead's significant gesture, as Costa suggests, but with Peirce's classification of signs. Of course, it is a kind of intersection that conveys big issues, and probably also the link between Peirce's phenomenology and semiotics has not been settled yet. However, this would be an interesting point to merge the two philosophies. 


\section{United Perspectives} a very different conception of necessity as "habit of action." Peirce's view of mathematics and our ways of "doing mathematics" through diagrams that conveys universals into particulars can be the phenomenological and semiotic path that we need in order to get to this profound comprehension of syntheticity. It would be also a concrete and fertile field of intersection between phenomenology and semiotics, a field that would exploit and develop the inspiring insight of Costa's book.

Pure Peirce scholars will object that in Peirce there is no room for any internalism and that we should better get rid also of the foundation of the self on our phenomenological knowledge. However, Costa does deny that we get to the self through an external, signdriven way, as far as we are describing the dynamic of reasoning. Only in a static dimension he stresses the foundation of the self on a continuity of time directly perceived, a dimension that classic pragmatists often downplayed favoring an inferential account. But this latter approach is not absolute and in any case it is worth discussing because in there we can find some of the most interesting suggestions of pragmatism about epistemology and metaphysics of the Self (see Calcaterra 2006) and of Continuity. Interestingly, the consistent understanding of this phenomenological perception as referred to the continuity of time seems to connect Costa's insight to the more advanced theories on mathematical intuitionism that use Husserl and Peirce at once (see Zalamea 2008). According to this approach we can maintain that phenomenology and pragmatism refer to the same essential world of possibilities. The real issue is to understand how these possibilities become actual and necessary, and how the concept of continuity plays a decisive role in this understanding.

In order to complete this insight about the way in which the continuity of possibilities involves actualities and necessities, we should deepen the concept of syntheticity, probably more than what Peirce and Husserl did. I think they remained caught in a too much 'like Kant' view of synthesis, in its turn tied to a particular view of necessity.

Peirce's semiotic can furnish the grammar for a different kind of syntheticity based on that would exploit and develop the inspiring insight of Costa's book.

\section{BIBLIOGRAPHY}

CALCATERRA R. M. (ed.), (2005), Semiotica e fenomenologia del sé, Torino, Aragno.

COSTA V., FRANZINI E. \& P. SPINICCI, (2002), La fenomenologia, Torino, Einaudi.

RoSenthal S. B. \& P. L. BouRgeors, (1983), Pragmatism and Phenomenology: A Philosophic Encounter, Amsterdam, Grüner.

HULSwIT M., (2002), From Cause to Causation. A Peircean Perspective, Dordrecht, Kleuwer Academic Publisher.

SHORT T. L., (2007), Peirce's Theory of Signs, Cambridge, Cambridge University Press. 
ZALAMEA F., (2008), Filosofia sintetica de las matematicas contemporaneas, Bogotà, Universidad Nacional de Colombia.

\section{AUTHORS}

GIOVANNI MADDALENA

Università del Molise

maddalena[at]unimol.it 